\title{
Üniversite Gençliğinin Vatandaşılı Hak Ve Sorumluluklarına İlişkin Bilinç Ve Farkındalıkları Üzerine Bir Araştırma: Isparta Meslek Yüksekokulu Örneği
}

\author{
Nilgün DOLMACI * \\ Nurdan KUŞAT ${ }^{* *}$
}

\section{ÖZET}

Bu çalışma üniversite ögrencilerinin vatandaşlık hak ve sorumluluklarına ilişkin bilinç ve farkındalık düzeylerini tespit etmek amacıyla gerçekleştirilmiştir. Bu amaç dahilinde Süleyman Demirel Üniversitesi Isparta Meslek Yüksekokulu Issletme Yönetimi ve Sağlık Kurumları Işsletmeciliği Programlarının 1. sınıflarında okuyan ögrencilere yönelik bir anket çalışması düzenlenmiştir. Çalışmada demografik ve iki grup içeren verilerin analizinde Student T Testi ile 2'den fazla seviye içeren faktörlerde (önşartlar sağlanıyor ise) varyans analizi tekniği ve (önşartlar sağlanmıyor ise) Kruskal-Wallis Testi ile gruplar arasındaki farklılıklar irdelenmiştir. Ankette elde edilen likert verilere faktör analizi uygulanarak toplam değişimi açılamada kaç faktörün etkili olduğu ve bu faktörler içerisinde de hangi soruların yüklerinin daha fazla olduğu irdelenmiştir. Katılımcıların siyasal hak ve ödevleri konusunda bilinç düzeylerinin yüksek olduğu ve siyasal hayata katılımda bu farkındalıklarını uygulamaya geçirmekten çekinmeyecekleri görülmüştür. Bireylerde hak arama bilincinin yerleşmesinde ĕgitimin etkili olduğuna ilişkin yerleşik bir kanaat bulunduğu saptanmıştır. Ayrıca ailenin yaklaşımına göre bireyin hak arama bilincinin etkilendiği görülmüştür.

Anahtar Kelimeler: Vatandaşlık Bilinci, Hak ve Sorumluluklar, Insan Hakları Eğitimi, Hak Bilinci, Temel Hak ve Özgürlükler.

JEL Sinıflandırması: I20, K19.

\begin{abstract}
A Study On The Awareness Level Of University Students Regarding Rights And Responsibilities Of Citizenship: Isparta Vocational School Case

ABSTRACT

The major aim of this study is to determine the awareness level of university students regarding rights and responsibilities of citizenship. Within this scope a survey was conducted for freshman students studying Business Management and Health Care Management Programs at Süleyman Demirel University, Isparta Vocational School. In the analysis part of research Student $T$ Test was used on data, which includes demographic and two groups; and, in factors including factors with more than 2 levels (if meet the requirements) variance analysis and technique were used, and (if do not meet the requirements) Kruskal-Wallis Test were used in order to evaluate the differences. By applying factor analysis on likert data obtained from survey, it was aimed to explain how many factors were effective on total change and which questions had more value among these factors. Participants' levels of awareness about political rights and duties are high and they would not hesitate to put their awareness into practice regarding participation to political life. It was found that there is a profound opinion that education is effective on advancement of awareness about claiming rights. In addition, awareness of claiming rights is affected depending upon the family's approach.
\end{abstract}

Keywords: Awareness of Citizenship, Rights and Responsibilities, Human Rights Education, Awreness of Rigts, The Basic Rigts and Freedoms.

Jel Classification: I20, K19.

\footnotetext{
* Öğr. Gör. Nilgün Dolmacı, Süleyman Demirel Üniversitesi, Isparta Meslek Yüksekokulu

** Öğr. Gör. Dr. Nurdan Kuşat, Süleyman Demirel Üniversitesi, Eğirdir Meslek Yüksekokulu, nurdankusat@sdu.edu.tr
} 


\section{GİRIŞ}

Toplumsal bir varlık olarak insan diğer tüm canlı varlıklardan farklı bir şekilde, kendine özgü yeteneklere sahiptir. Bu yetenekler; düşünme, konuşma, karar verme ve uygulama, zihinsel ve fiziksel gücünü kullanarak teknolojik, kültürel, ekonomik değerler üretme şeklinde belirtilebilir. Bu yeteneklerdeki sürdürülebilirlik ise, bireyin vatandaşlık bilincine sahip olmasına bağlı olarak sağlanabilir. Vatandaşlık bilinci de; başta insan hakları olmak üzere devlet, devletin fonksiyonları, idari ve yargısal yapılanma, sivil toplum kuruluşları vb. konularda bilgi sahibi olması ile kazandırılabilir. Vatandaşılık haklarının ve hak arama/koruma bilincinin ailede, okulda, özel ve iş yaşamında somut olarak yerleşmesi ile uygulama mümkün hale gelir. Bu bağlamda kendi hak ve sorumluluklarının farkında olan bireyler, geleceğini belirleme özgürlüğünü de elinde tutabilecektir.

Hak ve özgürlük bilgisi tüm haklara saygıyı güvence altına almak için temel bir araç olarak kabul edilir. Birleşmiş Milletler Genel Kurulu, İnsan Hakları Evrensel Bildirgesi’nde yer alan hakların gerçekleştirilmesi için bir merkezdir. Ocak 1995'den başlamak üzere "BM İnsan Hakları Eğitimi İçin 10 Yıl” sürecini ortaya koyarak, tüm sektörlerde insan hakları eğitim programlarının uygulanmasını geliştirmek adına Dünya İnsan Hakları Eğitim Programı'nı ilan etmiştir. Bu programda eğitim, tüm ülkeler arasında insan hakları ve temel özgürlüklere saygı, barış, adalet, eşitlik, hoşgörü gibi değerleri teşvik etmek zorundadır.

$\mathrm{Bu}$ gelişmelerin 1şığında Milli Eğitim Bakanlığı ile Türkiye Büyük Millet Meclisi arasında 13 Ocak 2004'te imzalanan bir protokolle "Demokrasi Eğitimi ve Okul Meclisleri Projesi" adıyla anılan proje, 2004-2005 eğitim-öğretim yılından itibaren ülke genelinde uygulanmaya başlamıştır. Demokrasi Eğitimi ve Okul Meclisleri Yönergesinin 5. maddesinde projenin amacı "Cumhuriyetimizin demokrasi ile güçlenmesi; öğrencilerimizde yerleşik bir demokrasi kültürünün oluşturulması, hoşgörü ve çoğulculuk bilincinin geliştirilmesi, kendi kültürünü özümsemiş, millî ve manevî değerlere bağlı, evrensel değerleri benimseyen nesillerin yetiştirilmesi; öğrencilere seçme, seçilme ve oy kullanma kültürünün kazandırılması; katılımcı olma, iletişim kurabilme, demokratik liderliği benimseyebilme ve kamuoyu oluşturabilme becerilerinin kazandırılması" şeklinde belirtilmektedir. Uygulanan bu proje; demokrasi, insan hakları temel hak ve özgürlüklerin sadece devlet tarafından bireylere tanınan ve korunan idealler olmaktan çıkmasını, toplumda özgürlük, eşitlik, çoğulculuk, farklılıklara saygı gibi siyasal ve kültürel bir yapının içselleştirilmesini sağlayacaktır.

Neticede, toplum halinde yaşamak bir zorunluluktur ve topluma dahil bireyler olarak gençlerin, toplumsal yaşamda sahip oldukları hakları, üzerlerine düşen sorumlulukları benimseyip benimsemedikleri önemli bir sorunsaldır. Bu bağlamda çalışmada amaç, temel hak ve özgürlükler, hak arama ve koruma mekanizmaları ve bunların davranışlara dönüştürülmesi hakkında, ön lisans öğrencilerinin bilinçli ve katılımcı vatandaş kimliklerinin ortaya konulması olarak belirlenmiştir. 


\section{HAK VE SORUMLULUKLARIN KAYNAĞI OLARAK TEMEL HAKLAR VE ÖDEVLER}

Çeçen'e göre (1995: 242) insan hakları, ilgisiz suskun ve katılımsız insan türünün bir ürünü değil, aksine tepki gösteren, gerçekleri ve inandıklarını açıkça söyleyebilen ve toplumsal yaşamın her aşamasına katılarak etkenlik gösterebilen aktif insan türünün bir ürünüdür.

Hak, kişinin toplumdan isteyebileceği, talep edebileceği ve kullanabileceği yetkilerdir. Bireyin haklarını kullanması, özgür olduğunu gösterir (Çüçen, 2011: 44). Freeman'a göre (2008: 7) haklar, sadece ahlaki ve/veya yasal kurallardan kaynaklanan talepler ve yetkilerdir. Her hak içinde ödev ve sorumluluğu da barındırır. Hak, özgürlük ve sorumluluk birbirlerini anlamlı hale getirir (Çüçen, 2011: 45). Özgürlük bütün hakların ortak kökeni, haklar ise özgürlükleri gerçekleştirmek için hukuk tarafından tanınan meşru yetkiler olduğu için; özgürlükler "yapabilmek" tir, haklar ise "istemek" tir (Duman ve diğerleri, 2003: 94).

Vatandaşlık hakları ve insan hakları öz itibariyle aynı kavramlardır. Bu yüzden ne şekilde adlandırılırsa adlandırılsın temel hak ve özgürlüklerin dayanağı pozitif hukuktur. 1982 Anayasası'nın "Temel Haklar ve Ödevler” başlıklı İkinci Kısmında, 12. maddede herkesin kişiliğine bağl1, dokunulmaz, devredilmez, vazgeçilmez temel hak ve özgürlüklere sahip olduğu ve bunların kişinin topluma, ailesine ve diğer kişilere karşı ödev ve sorumluluklarını da içerdiği hükme bağlanmıştır. Bu noktadan hareketle temel haklar şöyle tanımlanabilir; "temel haklar, devletin etki alanları karşısında, bireyin toplumsal özgürlük alanının anayasal garantileridir” (Gören, 2000: 17).

Hak ve özgürlüklerini bilmeyen kişiler, bu haklarını talep edemeyecekleri gibi, ihlal edilmesi halinde hangi kurum veya kuruluşa başvuracaklarını da bilemezler. Ayrıca, yasa ile düzenlenmesi gerektiği halde düzenlenmeyen hak ve özgürlükleri için yasal mücadele yollarını kullanamazlar (Duman ve diğerleri, 2003: 137). Zira, insan haklarının en önemli güvencesi, temel hak ve özgürlüklerinin bilincinde olan insanların kendisidir (Tezcan ve diğerleri, 2009: 56). Bu bilincin temeli yurttaşlık, devlet, demokrasi, insan hakları, temel toplumsal kurumlar ve cumhuriyet bilgisidir. Amaç, vatandaşların demokratik sisteme bilinçli ve sorumluluk sahibi bireyler olarak katılmasıdır (Ekşi, 2009: 20). İnsanlara, özellikle çocuklara ve gençlere felsefi temelleri olan bir eğitim verilmedikçe, temel kişi haklarının ve onlarla bağlantılı olarak diğer hakların korunması da mümkün görünmemektedir (Çotuksöken, 2010: 57).

Akdemir (2005: 79), "insanın değeri haklarının değeri kadardır" diyerek; hak ve yetkilerinin, sorumluluklarının farkında olan bireyin toplumsal, siyasal, sosyal ve ekonomik hayatta etkin rol oynayabileceğine gönderme yapmaktadır. $\mathrm{Bu}$ farkındalık aynı zamanda bireylerin birbirlerine karşı saygılı ve hoşgörülü davranması, demokrasi, özgürlük ve eşitliğin özümsenmesi, toplumda şiddetten çok barışın egemen olması anlamına gelir. Böylece insani değerlerin yükselmesi söz konusu olur. Zaten, insanlığın "fikir medeniyetinin" ürünleri arasında en onurlu, medeni ve değerlisi olduğu ifade edilmekte ve insanların ahlaken eşit ve 
özgür varlıklar olarak muamele görmesi ve muamele etmesi gerekliliğine işaret edilmektedir (Uslu, 2009: 18).

Vatandaşlık; bireye aile, okul, iş ortamı gibi mecralardan geçerek yaşadığı toplumsallaşma sürecinde öğretilen ve öğrenilen bir roldür. Hatta vatandaşlık gerek bilinç, gerek roller bağlamında toplumsal etkileşim ve ilişkiler çerçevesinde kurulur (Caymaz, 2007: 4). Vatandaşlık bilgisi; insanların vatanlarıyla, vatandaşlarıyla ve vatan üzerindeki kuruluşlarla karşıllklı ilişkilerini, sosyal kurallarla belirlenmiş hak ve sorumluluklarını kapsayan bilgi topluluğudur (Duman ve diğerleri, 2003:7).

Küreselleşme ve medya, internet ve iletişim alanındaki gelişmeler, insan haklarına evrensel bir anlam kazandırmış, uluslararası ilişkilerde "insan haklarına saygı" önemli bir ölçüt haline gelmiştir. Bahsi geçen konunun taşıdığı önem, gerek devleti gerekse vatandaşları bu konuda duyarlı olmaya ve kurallara uymada daha bilinçli davranmaya yöneltmektedir. (Tezcan ve diğerleri, 2009: 54). İnsan hakları, insan olmanın koşulu olduğu için herkesin bu haklara sahip çıkması ve koruması gerekir (Gören, 2011: 68).

\section{3. İNSAN HAKLARI EĞİTIMI}

İnsan hakları yaklaşımı herkesin özgürlük hakkına, ifade, inanç, örgütlenme, iyelik ve adil yargılanma özgürlüğüne sahip olduğu varsayımı ile başlar (Clapham, 2010: 135). İnsan hakları, bireyin onuru, özgürlük, eşitlik ve adalet değerlerine gönderimde bulunan bir değer olarak, kuşkusuz hiçbir zaman tümüyle ulaşılamayan, ancak toplum halindeki yaşama bir anlam kazandırmaya yönelik bir idealdir (Gündoğan ve Günay, 2004: 38). İnsan hakları ve demokrasi, sadece kabul edilip yasallaştırılmakla gerçekleşemez. Yaşayabilmesi için onun hem bilincinin yaratılması, hem de kişiler, uluslar ve uluslararası kuruluşlarca korunması gerekir (Altunya, 2003: 72).

İnsan hakları eğitimi ilk kez 1948 yılında İnsan Hakları Evrensel Bildirgesinde ifade edilmiş, sonrasında resmi ve gayri resmi ortamlarda farklı bileşenleri içerecek şekilde geliştirilmiştir. Bu eğitim; Bajaj' a (2012) göre; okul tabanlı eğitimi, okul sonrası programları, öğretmenlerden polislere, avukatlara ve hakimlere kadar uzanan atölye çalı̧malarını ve insan haklarıyla ilgili üniversite derslerini içerebilir. Bu çerçevede gerçekleştirilecek eğitim, demokrasinin ilke ve kurallarını, insan hak ve özgürlüklerinin eğitim programlarında açık ya da örtük hedeflere dönüştürülüp, öğrenme yaşantıları yoluyla toplumun genç bireylerine kazandırıldığı eğitim olmalıdır (Hotaman, 2010: 32). Bu bağlamda da insan hakları eğitimi; bilginin paylaşımı, becerilerin aktarımı ve davranışların şekillenmesi sayesinde evrensel bir insan hakları kültürünün oluşmasını amaçlayan eğitim, öğretim ve bilgi olarak tanımlanabilir (Bajaj, 2012).

İnsan Hakları Evrensel Bildirgesinin 26. maddesinin 2. fikrası; eğitimin insan kişiliğini tam geliştirmeye ve insan haklarıyla temel özgürlüklere saygıyı güçlendirmeye yönelik olması gerektiğini ifade etmektedir. Bu amaçla da insan hakları eğitiminin taşıması gereken unsurlar Birleşmiş Milletler (United Nations) (2006) tarafindan şu şekilde belirtilmektedir: 
i. İnsan hakları ve temel özgürlüklere saygının güçlendirilmesi,

ii. İnsan kişilik ve onur duygusunun tam gelişmesi,

iii. Tüm ülkeler arasında (yerli halklar ve 1rksal, ulusal, etnik, dini ve radikal grupların) anlayış, hoşgörü, cinsiyet eşitliği ve dostluğun teşviki,

iv. Herkesin hukuk kuralları ile yönetilen özgür ve demokratik toplumdaki etkin katılımının sağlanması,

v. Barışın inşası ve korunması,

vi. İnsan merkezli sürdürülebilir kalkınma ve sosyal adaletin teşvikinin sağlanması.

Soysal (1994) ve Suarez ve Ramirez' e (2004) göre ise insan hakları eğitimi; öğrencilerin ulusal vatandaşlıktan ziyade küresel vatandaşlığı iddia eden, uluslararası vatandaşlık hakları sayesinde gelişen uluslarüstü bir norm yapısına bağlılık geliştirmeleri anlamına gelir. Özetlemek gerekirse; insan hakları yaklaşımına dayalı kaliteli bir eğitim, bütün eğitim sisteminde ve tüm öğrenme ortamlarında uygulanan haklardır. Kuşkusuz, insan haklarına gerçek ve sürekli saygıyı sağlamanın asıl yolu, doğru bir insan hakları eğitimidir (Tezcan ve diğerleri, 2009: 55-56).

Demokratik değerlere ve insan haklarına saygılı bir kültür oluşturacak bu eğitimin, bireylere sadece bilginin üretiminde değil, haklarına sahip çıkma, demokratik değerleri ve insan haklarını koruma için aktif katılımda bulunarak gerekli becerileri kazandırma özelliklerini taşıması gerekir (Özpolat, 2010: 375). Unutulmamalıdır ki, insan kişiliğinin tam gelişmesi için olmazsa olmaz bir koşul olan insan haklarını ve demokrasiyi öğrenmek, başlı başına bir insan hakkıdır; dolayısıyla eğitim hakkının da önemli bir boyutudur (Altunya, 2003: 76).

Daha okul sıralarından itibaren bireyler, insan haklarını ve demokrasiyi uygulamalı öğrenerek gerçek yaşamlarında içselleştirebilirler ve yeni nesillerin içinde yaşayacağı daha demokratik bir toplum ve daha demokratik bir yönetim anlayışını egemen kılabilirler (Kıncal ve Uygun, 2006: 41).

\subsection{Hak Bilinci Edinilmesinde Eğitimin Rolü}

İnsan hakları eğitimi her zamankinden daha acil ve önemli bir gündem maddesi oluşturmaktadır. Gündemde olmasında ise demokratik bir şekilde yaşamanın zorluklarının artmasının (Osler ve Starkey, 2010) yanı sıra uluslararası politik tartışmalarda oldukça yaygın bir şekilde yer alması da (Bajaj, 2011) önemli bir rol oynamaktadır. Gerçekten de günümüzde yeni ekonomik düzenin bir getirisi olarak, ülkeler arasındaki sınırların kalkması, tüm toplumları gelişmişlik ve demokratlık derecelerine bakmaksızın birbirine sımsıkı bağlamış ve bağlamaya da devam etmektedir. Demokratik bir yönetimin ne anlama geldiğini bilmeyen toplumların, yıllardır demokratik bir yaşam sürmeye alışmış toplumlara adaptasyonu, bir hak ve özgürlükler ihlali silsilesine sebep olabilmektedir. İşte bu nedenle eğitim sistemleri, son dönemlerde daha fazla evrensel değerleri benimseyen ve küresel vatandaşlık bilincine sahip 
olan vatandaşları yetiştirmeye ağırlık vermektedirler (Kan, 2009: 26). Bajaj (2011) yaptığ1 çalışmada küresel vatandaşlı̆̆ı, bir arada yaşamayı ve bir ulus-devlet bağlamında gerçekleştirilmesi gereken uygulamaların oluşturduğu modelleri gözden geçirmekte, ayrıca insan hakları eğitiminin adaptasyon ve değişebilirlik gücünün olduğuna değinmektedir.

Bazı ülkeler ise, dışarıdan son derece demokratik, ayrıca eğitim ve kalkınmışlık düzeyleri son derece mükemmel görünmesine rağmen, vatandaşlık eğitimi konusunda benzer statüdeki ülkelerin gerisinde kalmaktadır. Bowring (2012) 1789 Fransız İhtilali ile gerçekleşen reformların neden en son İngiltere'ye geldiğini ve 20. yy' a ait ikinci nesil sosyal ve ekonomik hakların İngiltere' de benimsenmesine hala neden bu kadar çok karşı çıkıldığını araştırmaktadır. İngiltere gibi, pek çok konuda dünya ülkelerine liderlik etmiş bir ülkenin, halen bu tür tartışmalarla uğraşıyor olması şaşırtıcıdır. Kanımızca böyle bir tartı̧̧ma sadece demokrasi ile yakın geçmişte tanışmış olan ülkelerin gündeminde yer almalıdır.

Bireyin, kendisini tüm yönlerden geliştirebilmesi, yaşadığı çevreyi ve toplumu kavrayabilmesi, sorunlarına ilgi duyup çözümüne düşünsel ve eylemsel olarak katılması, toplumda etkin ve yararlı bir rol oynayabilmesi ve bu amaçla sorumluluklar üstlenebilmesi, öncelikle öznesi olduğu hak ve özgürlükleri öğrenerek "hak bilinci" edinmesine bağlidır (Gülmez, 1998: 3). Hak denen yetkinin kullanımı, ancak insanda hak bilincinin güçlenmesi ölçüsünde anlam, değer ve önem kazanır. Hak bilinci yeterince gelişip güçlenmemiş kişi neyin kendisine ait olduğunu kesinlikle bilmediği için, hakkına sahip çıkma olanağından yoksundur (Emini, 2004: 204). Hak ve sorumluluk bilincinin doğuştan edinilen veya kendiliğinden oluşan bir olgu (Özpolat, 2010: 368) olmaması nedeniyle, bir eğitim ve bilinçlendirme sürecinin sonunda kazanılması mümkündür.

Bireylerin, kendilerini ilgilendiren konulara ilişkin bilgi ve ilgi sahibi olduğu varsayımından hareketle, bu bilgiyi kararlara dönüştürecek hak arama, haklarını koruma, kamusal sorunlara katılım iradesinde de bulunmaları beklenir (Dağ1 ve Polat, 1999: 29). Ancak, bu beklentinin gerçekleşebilmesi için soyut söylemlerden çok, herkesin haklarını bilip öğrenmesi ve onları koruma ve kullanma bilincine varması için eğitim öğretim bir zorunluluktur (Gülmez, 1996: 7).

Vatandaşlık bir kimlik, siyasal bir topluluğa üyeliğin ifadesi olması yanında, bir dizi hak ve sorumluluk ile tanımlanan belirli bir statüdür (Kymlicka ve Norman, 2008: 207). Vatandaşlık, devlete hukuk bağı ile bağlanarak gerçekleştiği halde, hak ve sorumluluklarını bilen gerçek bir vatandaş olma niteliği "vatandaşllk eğitimi" ile kazanılır. Vatandaşlık eğitiminin temel amacı, kişi ile toplum arasındaki ilişkileri ve bu ilişkilerin yarattığı hak ve yükümlülükleri öğrenmektir (Altunya, 2003: 4).

$\mathrm{Bu}$ çerçevede, birey olma sorumluluğu, insanın kendi aklını bizzat kullanması, dünyayı algılayışında aklı merkeze alması, kendini ve toplumu ilgilendiren konulara ilgi duyması, sosyal yaşamın her alanına katılması esasına dayanır (Gündüz ve Gündüz, 2007: 3). Birey ve insan olma sorumluluğunu taşıyan her vatandaş da, her çeşit haksızlığa ve hakların çiğnenmesine karşı duyarlı olur (Çüçen, 2011: 72). Haklar ancak bireylerin haklarına saygı 
gösterilmesine yönelik etkinlikleri, ihlal karşısında duyarlılık dereceleri, haklarını sahiplenme yoğunluğu ve hatta gerektiğinde direnme yoluyla özgürlüklerini koruma bilinci sayesinde korunabilir (Coşkun, 2006: 233).

\section{2. İnsan Hakları Eğitiminde Uygulama Aşamaları}

Günümüzün bilinç düzeyi yükselen toplumu, özellikle uluslararası politik platformlarda insan hakları eğitiminin nasıl gerçekleştirileceği konusunda etkin bir şekilde görüşler üretmektedir. Bu eğitimin özellikle belirli alanlarda yoğunlaştırılması gerektiği yönünde fikir birlikteliği oluşmuştur. Flowers ve arkadaşları (2000), Tibbits (2008) ve Bajaj (2012) insan hakları eğitiminde uygulanması gerekenleri bir süreç dahilinde aşağıdaki gibi siralamaktadır:

i. Kişiler üzerinde insan hakları hakkında bir bilgi birikiminin yaratılması,

ii. İnsan hakları doğrultusunda kişisel değişimi sağlayacak davranış ve becerilerin teşvik edilmesi,

iii. Küresel, bölgesel ve yerel düzeydeki istismar durumlarında müdahale için eylem odaklı stratejilerin geliştirilmesi,

iv. İnsan hakları konusunda bireylerin farkındalığının yaygınlaştırılması.

Toplumsal bütünleşmeyi sağlama, birlikte yaşama imkanını üretme, bireylerin hayat standardını ve kalitesini yükseltme vb. değerleri sağlamanın yolu bireylere demokratik değer ve becerileri kazandırmaktır. Gelişmiş toplumlara bakıldığında, giderek artan bir şekilde eşitlik, insan hakları, özgürlük, hukukun üstünlüğü, diyalog ve hoşgörü, saydamlık, çoğulculuk, çevre bilinci vb. alanlarda kayda değer gelişmelerin sağlandığ 1 görülmektedir (Özpolat, 2010: 368-372). Bunun ön koşulunun ise, demokrasi, insan hakları, hakları kullanma ve koruma yolları konusunda demokratik bir eğitimdir. Ayrıca, Doğan (2007:287) eğitimin, siyaset ve hukuk gibi yaptırım mekanizmalarına gerek kalmaksızın insan haklarının korunma ve geliştirilmesinde en önemli etken olduğuna vurgu yapmaktadır.

$\mathrm{Bu}$ arada unutulmaması gereken bir konu da, insan hakları eğitimi konusunda kendilerine pek çok iş düşen öğretmenlerin bu konudaki bilgilerinin yeterli düzeyde olması gereğidir. Gündoğdu'nun (2011) çalışma sonuçları öğretmen yetiştiren kurumlarda insan hakları eğitimine ihtiyaç olduğunu göstermektedir. Bu bağlamda "insan hakları eğitimi, eğitimi gerçekleştirecek olan eğitmenlerin eğitimiyle başlar" demek doğru olacaktır.

\section{4. ÖRNEK UYGULAMA}

$\mathrm{Bu}$ çalışma Süleyman Demirel Üniversitesi Isparta Meslek Yüksekokulu İşletme Yönetimi ve Sağlık Kurumları İsletmeciliği Programlarının 1. sınıflarında eğitim gören birinci ve ikinci öğretim öğrencilerinin tümüne uygulanmıştır. Toplam kayıtlı öğrenci sayısı 220 olup, bunlardan 197 tanesine ulaşılmış ve bu öğrencilerin ankete katılımları sağlanmıştır. 


\section{1. İstatistik Metod}

Çalışmada demografik verilere ait rakamlar sayı ve yüzde olarak tablo halinde gösterilmiştir. 5'li likert olarak sorulan sorulara verilen cevaplar da yine sayı ve yüzde olarak tablo halinde gösterilmiş̧ir. Likert sorulara verilen puanların toplanıp ortalaması alınarak, ortalama şeklinde veriler elde edilmiştir. Bu ortalama veri kişinin hak arama bilincini temsil etmektedir.

Çalı̧̧mada cinsiyet, ayrımcılı̆ga maruz kalma, ayrımcılıkla mücadele yollarını bilme, hak aramada cinsiyet farklılığ , hak aramada eşitlik, adli yardım uygulaması, hak ihlalinde başvurulacak makam ve başka birisinin hak ihlaline tepki gibi demografik ve iki grup içeren verilerin analizinde Student T Testi kullanılmıştır.

Anne ve baba eğitimi, mezun olunan lise türü, okunmakta olunan bölüm, yasal hakların öğrenilme yeri, haksızlığa karşı en etkili çözüm ve bireysel hakları gözeten kurum gibi 2'den fazla seviye içeren faktörlerde hak arama bilinci ortalamaları bakımından parametrik testlerin ön şartlarının sağlanıp sağlanmadığı test edilmiştir (Varyansların homojenliği Bartlets Testi ile, normal dağılıma uyum Kolmogorov-Smirnov Testi ile kontrol edilmiştir). Ön şartlar sağlanıyor ise varyans analizi tekniği ile, ön şartlar sağlanmıyor ise Kruskal-Wallis Testi ile gruplar arasındaki farklılıklar irdelenmiştir.

Yapılan anketin güvenilirliğini test etmek için Cronbach's Alpha katsayısı hesaplanmıştır. Ankette elde edilen likert verilere faktör analizi uygulanarak toplam değişimi açıklamada kaç faktörün etkili olduğu ve bu faktörler içerisinde de hangi soruların yüklerinin daha fazla olduğu irdelenmiştir. Faktör analizi yapılmadan önce analizin ön şartları olan Kaiser-Meyer-Olkin Test istatistiği ile Bartlet'in küresellik ön şartı incelenmiş ve ön şartların yerine geldiği görülmüş̧ür.

\subsection{Analiz Sonuçları}

Anket sorularının Süleyman Demirel Üniversitesi Isparta Meslek Yüksekokulu'nda İşletme Yönetimi ve Sağlık Kurumları İşletmeciliği 1. Sınıfta okuyan 220 öğrenciye uygulanması hedeflenmiş, fakat bu öğrencilerden 197 tanesine ulaşılabilmiştir. Bu öğrencilere ait cinsiyet, anne ve baba eğitim düzeyleri, mezun olunan lise türü ve okudukları bölümlere ilişkin bazı demografik bilgiler Tablo 1'de gösterilmektedir. 
Tablo 1: Katılımcılara Ait Demografik Bilgiler

\begin{tabular}{|c|c|c|c|}
\hline \multirow[t]{2}{*}{ Cinsiyet } & Bay & 88 & 44,67 \\
\hline & Bayan & 109 & 55,33 \\
\hline \multirow{4}{*}{ Anne Eğitimi } & İlkokul & 112 & 56,85 \\
\hline & Ortaokul & 40 & 20,30 \\
\hline & Lise & 35 & 17,77 \\
\hline & Yüksekokul & 10 & 5,08 \\
\hline \multirow{5}{*}{ Baba Ĕ̆itimi } & İlkokul & 78 & 39,59 \\
\hline & Ortaokul & 53 & 26,90 \\
\hline & Lise & 52 & 26,40 \\
\hline & Yüksekokul & 8 & 4,06 \\
\hline & Fakülte & 6 & 3,05 \\
\hline \multirow{5}{*}{ Mezun Olunan Lise } & Düz Lise & 50 & 25,38 \\
\hline & Anadolu Lisesi & 9 & 4,57 \\
\hline & Ticaret Lisesi & 85 & 43,15 \\
\hline & Anadolu Ticaret Lisesi & 33 & 16,75 \\
\hline & Herhangi Bir Ana. Meslek Lisesi & 20 & 10,15 \\
\hline \multirow{2}{*}{$\begin{array}{l}\text { Okunmakta Olan } \\
\text { Bölüm }\end{array}$} & İşletme Yönetimi & 132 & 67,01 \\
\hline & Sağlık İşletmeciliği & 65 & 32,99 \\
\hline
\end{tabular}

\subsubsection{T Testi Sonuçları}

Hak arama bilinci ortalama puanı ve aşağıdaki özelliklerin ortalamaları arasındaki farklar test edilerek Tablo 2'de gösterilmiştir.

- Cinsiyetin,

- Herhangi bir nedenle ayrımcılığa maruz kalıp kalmayanların (cinsiyet, inanç, kişisel özellikler, düşünceler vb.),

- Herhangi bir nedenle ayrımcılığa maruz kalma durumunda mücadele yollarını bilenler ve bilmeyenlerin,

- Hak arama bilincinin cinsiyete göre değişip değişmediğini düşünenlerin,

- Hak arama özgürlüğünde vatandaşlar arasında eşitliğin olup olmadığına inananların,

- Hak arama güvencesi olarak adli yardım uygulamasının farkında olup olmayanların,

- Hak aramada başvurulacak makamı bilip bilmeyenlerin,

- Bir başka bireyin hak ihlaline uğraması durumunda harekete geçip geçmemeyi düşünmenin, ortalamaları arasındaki fark test edilmiş ve sonuç Tablo 2'de gösterilmiştir.

Hak arama bilinci ortalama puanı bakımından yapılan $t$ testi sonucunda;

- cinsiyetin,

- herhangi bir nedenle ayrımcılığa maruz kalıp kalmayanların (cinsiyet, inanç, kişisel özellikler, düşünceler vb.),

- herhangi bir nedenle ayrımcılığa maruz kalma durumunda mücadele yollarını bilenler ve bilmeyenlerin,

- hak arama bilincinin cinsiyete göre değiş̧ip değişmediğini düşünenlerin,

- hak arama güvencesi olarak adli yardım uygulamasının farkında olup olmayanların, 
- hak aramada başvurulacak makamı bilip bilmeyenlerin,

- bir başka bireyin hak ihlaline uğraması durumunda harekete geçip geçmemeyi düşünmenin, ortalamaları arasındaki fark istatistik olarak önemli değildir.

Tablo 2: Hak Arama Bilinci Ortalamaları ile Belirlenen Özelliklerin Ortalamaları Arasındaki Farklar

\begin{tabular}{|c|c|c|c|c|}
\hline & & Sayı & Ortalama & Standart Sapma \\
\hline \multirow{3}{*}{ Cinsiyet } & Bay & 88 & 3,628 & 0,738 \\
\hline & Bayan & 109 & 3,698 & 0,647 \\
\hline & \multicolumn{4}{|c|}{$P=0,479$} \\
\hline \multirow{3}{*}{$\begin{array}{l}\text { Ayrımcılı̆ga } \\
\text { Maruz } \\
\text { Kalma } \\
\end{array}$} & Evet & 63 & 3,587 & 0,710 \\
\hline & Hayır & 134 & 3,705 & 0,678 \\
\hline & \multicolumn{4}{|c|}{$P=0,266$} \\
\hline \multirow{3}{*}{$\begin{array}{l}\text { Ayrımcilıkla } \\
\text { Mücadele } \\
\text { Bilinci } \\
\end{array}$} & Evet & 142 & 3,676 & 0,732 \\
\hline & Hayır & 55 & 3,643 & 0,564 \\
\hline & \multicolumn{4}{|c|}{$P=0,759$} \\
\hline \multirow{3}{*}{$\begin{array}{l}\text { Hak Arama Bilincinin } \\
\text { Cinsiyete } \\
\text { Göre Değişimi }\end{array}$} & Evet & 91 & 3,635 & 0,670 \\
\hline & Hayır & 106 & 3,695 & 0,706 \\
\hline & \multicolumn{4}{|c|}{$P=0,543$} \\
\hline \multirow{3}{*}{$\begin{array}{l}\text { Hak } \\
\text { Aramada } \\
\text { Eşitlik } \\
\end{array}$} & Evet & 79 & 3,568 & 0,786 \\
\hline & Hayır & 118 & 3,733 & 0,609 \\
\hline & \multicolumn{4}{|c|}{$P=0,099$} \\
\hline \multirow{3}{*}{$\begin{array}{l}\text { Adli } \\
\text { Yardım } \\
\text { Bilinci }\end{array}$} & Evet & 48 & 3,577 & 0,719 \\
\hline & Hayır & 149 & 3,696 & 0,678 \\
\hline & \multicolumn{4}{|c|}{$P=0,300$} \\
\hline \multirow{3}{*}{$\begin{array}{l}\text { Başvuruda Bulunulacak } \\
\text { Makam } \\
\text { Farkındalığı } \\
\end{array}$} & Evet & 123 & 3,702 & 0,699 \\
\hline & Hayır & 74 & 3,609 & 0,671 \\
\hline & \multicolumn{4}{|c|}{$P=0,359$} \\
\hline \multirow{3}{*}{$\begin{array}{l}\text { Başka Bireyin } \\
\text { Hak İhlaline } \\
\text { Karşı Tepki }\end{array}$} & Evet & 149 & 3,699 & 0,696 \\
\hline & Hayır & 48 & 3,569 & 0,661 \\
\hline & \multicolumn{4}{|c|}{$\mathrm{P}=0,256$} \\
\hline
\end{tabular}

Hak arama bilinci ortalama puanı bakımından yapılan t testi sonucunda, hak arama özgürlüğünde vatandaşlar arasında eşitliğin olup olmadığına inananların ortalamaları arasındaki fark istatistik olarak önemlidir. $(\mathrm{P}<0,10)$. Bu istatistik sonuç, katılımcıların hak arama bilinç düzeylerinin, hak arama özgürlügünün kullanımında vatandaşlar arasında eşitlik olduğuna inanmamaları nedeniyle olumsuz etkilenebileceğinin bir göstergesi olarak değerlendirilebilir. Çünkü hak arama bilinci, hak aramada eşitlik olduğuna inanılması durumunda yıpranacak ve ilgili alanda bir bilinç gerilemesine sebep olabilecektir.

\subsubsection{Kruskal-Wallis Testi Sonuçları}

Anne eğitim durumu, baba eğitim durumu ve mezun olunan lisenin; hak arama bilinci puan ortalaması bakımından farklı olup olmadı̆̆ irdelenmeden önce yapılan Bartlett's testi ve Kolmogorov-Smirnov testleri sonucunda parametrik testlerin önşartlarının sağlanmadığ görülmüş ve parametrik olmayan testlerden Kruskal-Wallis testi uygulanmıştır. Elde edilen sonuçlar Tablo 3'de sunulmaktadır. 
Tablo 3: Hak Arama Bilinci ve Anne-Baba Eğitimi-Mezun Olunan Lise

\begin{tabular}{|c|c|c|c|c|}
\hline \multirow{7}{*}{ Anne Eğitimi } & & Sayı & Medyan & Ave Rank \\
\hline & İlkokul & 112 & 3,824 & 93,9 \\
\hline & Ortaokul & 40 & 3,824 & 93,0 \\
\hline & Lise & 35 & 4,000 & 116,4 \\
\hline & Yüksekokul & 10 & 4,000 & 119,8 \\
\hline & Toplam & 197 & & 99,0 \\
\hline & \multicolumn{4}{|c|}{$P=0,115$} \\
\hline \multirow{7}{*}{ Baba Eğitimi } & İlkokul & 78 & 3,765 & 91,2 \\
\hline & Ortaokul & 53 & 3,882 & 96,1 \\
\hline & Lise & 52 & 3,941 & 106,1 \\
\hline & Yüksekokul & 8 & 4,118 & 128,3 \\
\hline & Fakülte & 6 & 4,059 & 125,0 \\
\hline & Toplam & 197 & & 99,0 \\
\hline & \multicolumn{4}{|c|}{$P=0,219$} \\
\hline \multirow{6}{*}{ Mezun Olunan Lise } & Düz Lise & 50 & 3,941 & 110,1 \\
\hline & Anadolu Lisesi & 9 & 3,471 & 78,2 \\
\hline & Ticaret Lisesi & 85 & 3,706 & 87,6 \\
\hline & Anadolu Ticaret Lisesi & 33 & 3,941 & 113,7 \\
\hline & Herhangi Bir Ana. Mes.Lisesi & 20 & 3,941 & 104,8 \\
\hline & Toplam & 197 & & 99,0 \\
\hline
\end{tabular}

Yapılan Kruskal-Wallis testi sonucunda hak arama bilinci puan ortalamaları bakımından anne ve baba eğitim durumlarının medyanları arasındaki farklar istatistik olarak önemli değildir. Fakat hak arama bilinci puan ortalamaları bakımından katılımcıların mezun oldukları lise durumlarının medyanları arasındaki farklar istatistik olarak önemlidir $(\mathrm{P}<0,10)$. Katılımcıların mezun oldukları lisenin hak arama bilinci üzerinde etkili olduğu anlaşılmıştır.

\subsubsection{Anova Testi Sonuçları}

Yasal hakların öğrenilme yerlerinin, haksızlığa uğranıldığında başvurulabilecek en etkili yolun ve bireysel hakları en fazla gözeten kurumun seviye ortalamaları arasındaki farkların irdelenmesinde önşartlar sağlandığı için tek yönlü varyans analizi yapılmıştır. Yapılan analiz sonucunda; yasal hakların öğrenilme yerlerinin $(\mathrm{P}=0,088)$, haksızlığa uğranıldığında başvurulabilecek en etkili yolun $(\mathrm{P}=0,02)$ ve bireysel hakları en fazla gözeten kurumun $(\mathrm{P}=0,001)$ seviye ortalamaları arasındaki farklar istatistik olarak önemlidir $(\mathrm{P}<0,10)$.

Seviye ortalamaları arasındaki farklılıklar Tukey testi ile irdelenmiştir. Bu analize ait veriler Tablo 4'de yer almakta olup, hangi seviyelerin birbirinden farklı olduğu ortalamalar üzerinde Latin harfleri ile gösterilmiştir. 
Tablo 4: Tukey Testi Sonuçları

\begin{tabular}{|l|c|c|c|}
\hline Yasal Hakların Öğrenilme Yeri & Sayı & Ortalama & \multicolumn{1}{l|}{ Grup } \\
\hline Gazete/TV/İnternet & 139 & 3,7241 & A \\
\hline Okul & 24 & 3,7230 & A B \\
\hline Çevrede Konuşulanlar & 15 & 3,5373 & A B \\
\hline Bilmiyorum & 4 & 3,4853 & A B \\
\hline Kitap & 15 & 3,2275 & B \\
\hline $\begin{array}{l}\text { Haksılık Durumunda } \\
\text { Başvurulacak Yer }\end{array}$ & & & \\
\hline Yetkili Makamlara Başvurma & 148 & 3,7512 & A \\
\hline Sessiz Kalma & 6 & 3,6667 & A B \\
\hline Şiddete Başvurma & 8 & 3,5588 & A B \\
\hline İkna ve İnandırma & 31 & 3,3776 & B \\
\hline Taviz Verme & 4 & 3,0147 & A B \\
\hline Bireysel Hakları Gözeten Kurum & & & \\
\hline Avukatlar & 5 & 4,1882 & A \\
\hline Mahkemeler & 77 & 3,8182 & A \\
\hline Bizzat Kendim & 71 & 3,6106 & A \\
\hline Emniyet Kuvvetleri & 37 & 3,5374 & A B \\
\hline Siyasi Partiler ve Siyasetçiler & 7 & 2,8908 & B \\
\hline
\end{tabular}

Tablo 4 incelendiğinde;

- Yasal hakların öğrenilme yerleri açısından sadece gazete/TV/internet ve kitaptan yasal haklarını öğrendiklerini ifade eden grupların ortalamaları arasındaki farklar istatistik olarak önemli bulunmuştur $(\mathrm{P}<0.10)$. Katılımcılara yasal haklarını nereden öğrendikleri sorulduğunda; alınan cevaplarda ve yapılan istatistik sonucunda okuldan ve kitaplardan öğrendiklerini söyleyenler arasında fark bulunmadığı görülmüştür ki, bu durum birbirini tamamlayıcı bir yapı sergilemektedir. Bu sonuç hak arama bilincinin gelişmesinde eğitimin önemli bir unsur olduğunun bir göstergesi olarak değerlendirilebilir.

- Haksızlık durumunda başvurulacak yer açısından sadece yetkili makamlara başvurma ve ikna/inandırma yöntemlerini kullanacaklarını ifade eden grupların ortalamaları arasındaki farklar istatistik olarak önemli bulunmuştur $(\mathrm{P}<0.10)$. Haksızlık durumunda katılımcıların yetkili makamlara başvurma tercihini kullanmaları ile başvuruda bulunmayıp sessiz kalmaları arasında fark bulunmaması dikkat çekmektedir. Aynı sonuç haksızlıkla karşılaşıldığında yetkili makamlara başvurma ve taviz verme davranışları için de söz konusudur. Katılımcıların haksızlığa maruz kalma durumunda başvuru yapacakları yerler arasında mevcut hukuk sistemine uygunluk açısından böylesine büyük bir farklılık varken, istatistik sonucunun farklılık olmadığ yönünde çıkması, katılımcıların hak arama bilinçlerinin tam olarak gelişmediğinin bir göstergesi olarak değerlendirilebilir.

- Bireysel hakları gözeten kurumlar açısından siyasi partiler ve siyasetçiler ile avukatlar, mahkemeler, bizzat kendim diyen grupların ortalamaları arasındaki farklar istatistik olarak önemli bulunmuştur $(\mathrm{P}<0.10)$. Bireysel haklarının en fazla hangi kurum tarafından gözetildiği sorulan katılımcıların verdiği cevaplarda "bizzat kendim hakkımı gözetirim” diyenlerle, "avukatlar, mahkemeler ve emniyet kuvvetleri haklarımı gözetir" diyenler arasında 
bir fark olmadığı görülmüştür. Bu istatistik sonuç da hak arama konusunda birbirinden çok farklı iki davranış biçimini birbirine yakınlaştırmaktadır. Bu durum da katılımcıların hak arama bilinçlerinin tam olarak gelişmediğini söylemek mümkün olabilir.

\subsubsection{Faktör Analizi}

Çalışmada likert tiple elde edilen verilere ait güvenliğin incelenmesi bakımından Crombach's Alpha test istatistiği uygulanmış ve bu değer 0,87 olarak bulunmuştur. Bu da anketin sonuçlarının güvenilirliğini göstermektedir.

Faktör analizi yapmadan önce hesaplanan Kaiser-Meyer-Olkin test istatistiği de 0,89 olarak bulunmuş olup, önşartın yerine geldiği görülmektedir. Bartlett'in küresellik önşartı da sağlanmaktadır. Tablo 5'de sonuçlar verilmektedir.

Tablo 5: Faktör Analizi Önşart Koşulları

\begin{tabular}{|l|l|c|}
\hline \multicolumn{3}{|c|}{ KMO and Bartlett's Test } \\
\hline Kaiser-Meyer-Olkin Measure of Sampling Adequacy &, 891 \\
\hline \multirow{3}{*}{ Bartlett's Test of Sphericity } & Approx. Chi-Square & 1382,274 \\
\cline { 2 - 3 } & Df & 136 \\
\cline { 2 - 3 } & Sig. &, 000 \\
\hline
\end{tabular}

Tablo 6 incelendiğinde yapılan faktör analizi sonucunda ilk 4 faktörün öz değerinin birden büyük olduğu görülmektedir. Bu yüzden toplam değişimi açıklamada bu 4 faktör en fazla yüke sahip olmuştur. Bu 4 faktör toplam değişimin \% 61 'ini açıklamaktadır. 1. Faktör toplam değişimin \%38,17'sini, 2. Faktör \%9,38'ini, 3. Faktör \%7,18'ini ve 4. Faktör de \%5,89'unu açıklamaktadır.

Tablo 6: Faktör Analizi Sonuçları

\begin{tabular}{|l|l|c|c|l|c|}
\hline \multicolumn{5}{|c|}{ Total Variance Explained } \\
\hline \multirow{3}{*}{ Component } & \multicolumn{2}{|l|}{$\begin{array}{l}\text { Extraction } \\
\text { Squared Loadings }\end{array}$} \\
\cline { 2 - 6 } & Total & \% of Variance & Cumulative \% & Total & \% of Variance \\
\hline $\mathbf{1}$ & 6,489 & 38,169 & 38,169 & 6,489 & 38,169 \\
\hline $\mathbf{2}$ & 1,595 & 9,382 & 47,551 & 1,595 & 9,382 \\
\hline $\mathbf{3}$ & 1,220 & 7,178 & 54,729 & 1,220 & 7,178 \\
\hline $\mathbf{4}$ & 1,001 & 5,885 & 60,614 & 1,001 & 5,885 \\
\hline $\mathbf{5}$ & 0,935 & 5,501 & 66,115 & & \\
\hline $\mathbf{6}$ & 0,835 & 4,915 & 71,029 & & \\
\hline $\mathbf{7}$ & 0,723 & 4,250 & 75,280 & & \\
\hline $\mathbf{8}$ & 0,676 & 3,974 & 79,254 & & \\
\hline $\mathbf{9}$ & 0,578 & 3,400 & 82,654 & & \\
\hline $\mathbf{1 0}$ & 0,535 & 3,149 & 85,803 & & \\
\hline
\end{tabular}




\begin{tabular}{|l|l|l|l|l|l|}
\hline $\mathbf{1 1}$ & 0,481 & 2,830 & 88,633 & & \\
\hline $\mathbf{1 2}$ & 0,425 & 2,499 & 91,132 & & \\
\hline $\mathbf{1 3}$ & 0,388 & 2,284 & 93,417 & & \\
\hline $\mathbf{1 4}$ & 0,354 & 2,080 & 95,496 & & \\
\hline $\mathbf{1 5}$ & 0,295 & 1,735 & 97,232 & & \\
\hline $\mathbf{1 6}$ & 0,254 & 1,492 & 98,724 & & \\
\hline $\mathbf{1 7}$ & 0,217 & 1,276 & 100,00 & & \\
\hline
\end{tabular}

Extraction Method: Principal Component Analysis.

Faktör analizinde metod olarak temel bileşenler yöntemi, veri döndürme yöntemi olarak da Varimax yöntemi kullanılmıştır. Kullanılan bu yöntemler sonucunda elde edilen veriler Tablo 7'de yer almaktadır.

Tablo 7: Temel Bileşenler ve Varimax Yöntemi Sonuçları

\begin{tabular}{|c|c|c|c|c|}
\hline \multicolumn{5}{|c|}{ Rotated Component Matrix } \\
\hline \multirow{3}{*}{ Sorular } & $\begin{array}{c}\mathbf{1} \\
\text { Sosyal, Ekonomik ve } \\
\text { Siyasal Faktör }\end{array}$ & $\begin{array}{c}\mathbf{2} \\
\text { Eşitlik Faktörü }\end{array}$ & $\begin{array}{c}\text { 3 } \\
\text { Eğitim Faktörü }\end{array}$ & $\begin{array}{c}\mathbf{4} \\
\text { Aile Faktörü }\end{array}$ \\
\hline $\mathbf{1}$ & 0,128 & 0,013 & 0,824 & $-0,073$ \\
\hline $\mathbf{2}$ & 0,103 & 0,339 & 0,694 & 0,226 \\
\hline $\mathbf{3}$ & 0,234 & 0,162 & 0,356 & 0,604 \\
\hline $\mathbf{4}$ & $-0,033$ & 0,175 & $-0,090$ & 0,770 \\
\hline $\mathbf{5}$ & 0,231 & 0,726 & 0,315 & 0,101 \\
\hline $\mathbf{6}$ & 0,296 & 0,610 & 0,159 & 0,098 \\
\hline $\mathbf{7}$ & 0,289 & 0,600 & 0,141 & 0,246 \\
\hline $\mathbf{8}$ & 0,536 & 0,590 & 0,137 & 0,254 \\
\hline $\mathbf{9}$ & 0,342 & 0,593 & 0,146 & 0,225 \\
\hline $\mathbf{1 0}$ & 0,762 & 0,156 & $-0,080$ & $-0,053$ \\
\hline $\mathbf{1 1}$ & 0,712 & 0,118 & 0,145 & $-0,272$ \\
\hline $\mathbf{1 2}$ & 0,238 & $-0,729$ & 0,224 & 0,075 \\
\hline $\mathbf{1 3}$ & 0,647 & 0,292 & 0,183 & 0,159 \\
\hline $\mathbf{1 4}$ & 0,647 & 0,353 & 0,172 & 0,291 \\
\hline $\mathbf{1 5}$ & 0,499 & 0,472 & 0,163 & 0,308 \\
\hline $\mathbf{1 6}$ & 0,633 & 0,413 & 0,167 & 0,136 \\
\hline $\mathbf{1 7}$ & 0,596 & $-0,134$ & 0,156 & 0,269 \\
\hline
\end{tabular}

Extraction Method: Principal Component Analysis.

Rotation Method: Varimax with Kaiser Normalization.

a. Rotation converged in 7 iterations. 
Tablo 7'yi incelediğimizde, bu 4 faktörden en yüksek varyans açıklama miktarının 1. Faktöre ait olduğu görülmektedir. 1. Faktörde en yüksek yüklere sahip sorular ise $10(0,762)$, 11 (0,712), 13 (0,647), 14 (0,647), $16(0,633)$ ve 17. (0,596) sorular olmuştur. Bu sorular "siyasi partilere üyelik”, “sendikalara üyelik”, “fikirlerin özgürce dile getirilmesi”, “ekonomik adalet", "toplumsal hak ve özgürlüklere saygı" ve "toplumsal hizmetlerden yararlanma" bilincini ölçmeye çalışan sorulardır. Bu gerekçeyle Faktör 1 "Sosyal, Ekonomik ve Siyasal Faktör" olarak isimlendirilmiştir. Özellikle katılımcıların siyasal hak ve ödevleri konusunda bilinç düzeylerinin yüksek olduğu ve siyasal hayata katılımda bu farkındalıklarını uygulamaya geçirmekten çekinmeyecekleri görülmüştür.

Faktör 2 incelendiğinde en yüksek yüklere sahip sorular $5(0,726), 6(0,610), 7$ $(0,600), 8(0,590)$ ve 9 . $(0,593)$ sorular olmuştur. Bu sorular "bireylerin cinsiyetlerine ve cinsel tercihlerine bakılmaksızın her konuda "hak arama", "iş başvurusu ve çalışma hakkı", "adil davranış ve adil yargı hakkı" ve "eğitim hakkı" kapsamındaki eşitlik ilkelerinden yararlanma özgürlügünün önemine yönelik inancı değerlendirmektedir. Bu nedenle Faktör 2 "Eşitlik Faktörü" olarak isimlendirilmiştir. Bu faktörde katılımcıların eşitliğin cinsiyet boyutuyla ilgili olumlu yaklaşımlarının ağırlık taşıdığı ortaya çıkmıştır.

Faktör 3'de $1(0,824)$ ve 2. $(0,694)$ sorular en yüksek yüklere sahip olan sorulardır. Bu sorular katılımcıların tüm eğitim dönemleri boyunca "hak arama bilinçlerinin geliştirilmesi yönünde eğitim aldıklarına" ve "hak arama bilincinin yerleşmesinde eğitimin rolünün yüksek olduğuna" dair inançlarını test etmektedir. Bu nedenle Faktör 3 "Eğitim Faktörü" olarak isimlendirilmiştir. Katılımcıların bireylerde hak arama bilincinin yerleşmesinde eğitimin etkili olduğuna ilişkin yerleşik bir kanaat bulunduğu saptanmıştır.

Faktör 4 de ise $3(0,604)$ ve 4 . $(0,770)$ sorular en yüksek yüklere sahip sorular olarak bulunmuştur. $\mathrm{Bu}$ sorular "hak arama bilincinin yerleştirilmesinde ailenin etkisini" ve katılımcıların haklarını aramada "hakkımı yeterince arayamazsam" endişesini sorgulayan sorular olduğu için, Faktör 4 "Aile Faktörü” olarak isimlendirilmiştir. Elde edilen bu sonuç; hak arama bilincinin yerleştirilmesi ve hakkın aranması açısından özgüvenin oluşmasında, ailenin etkisinin yoğun olduğunu istatistik olarak göstermektedir. Sonuç itibariyle ailenin bireye yaklaşımına göre bireysel hak arama bilinci olumlu ya da olumsuz bir şekilde etkilenmektedir.

\section{SONUÇ}

Hak ve sorumluluk bilincinin olmazsa olmaz koşulu eğitimdir ve eğitimin ilk kademelerinden itibaren hak ve sorumlulukların öğrenilip özümsenmesi bir zorunluluktur. İletişim ve teknolojinin gelişmesiyle hız kazanan küresel oluşumlar neticesinde, yaşam boyu eğitim önem kazanmıştır. Hak ve sorumluluk bilincinin yerleştirilmesi ve sürdürülebilir kılınmasında da eğitim uzun soluklu bir süreç olarak değerlendirilebilir. 
Temel hakların ve bu bağlamda vatandaşlık hak ve sorumluluklarının ne olduğunun açık ve net şekilde bilinmeyişi, hakların kullanımına ve korunmasına ilişkin bilinç düzeyinin yeterli olmayışı toplumsal saygı ve hoşgörünün azalmasına ve demokrasi, özgürlük ve eşitliğin ivme kaybetmesine yol açar.

Bireylere temel hak ve özgürlüklerin devlet tarafından tanınması ve korunmas1 zorunludur. Ancak, bireye hak ve özgürlükleri konusunda -çocukluktan gençliğe uzanan dönemde- temel bir eğitim verilmedikçe, bunların hukuksal metinlerde yer almasının anlamı olmayacaktır. Kendi hak, özgürlük ve sorumluluklarının farkında olan birey, bir vatandaş olarak hakların kullanma, özgürlüklerinin sınırlarını kavrama ve toplumsal sorumluluklarını yerine getirme hususlarında bir açmaza düşmeden adım atma cesaretine sahip olacaktır. Eğitim ile vatandaşlara "hak bilinci" kazandırılması esasen bireysel özgürlüğün anahtarı olarak görünmektedir.

Demokrasi, insan hakları ve temel hak ve özgürlükler konusunda eğitimin önemini vurgulamaya yönelik gerçekleştirilen çalışmamızdan elde edilen bulgulara göre, vatandaşlık hak ve sorumlulukları, hakların korunması yol ve yöntemleri konularında hedef kitlenin genel bir fikir sahibi olmadıkları tespit edilmiştir. Bu bağlamda hedef kitlenin;

- Haklar konusunda bilgi düzeylerinin yetersiz ya da çelişkili olduğu,

- Bilgi sahibi oldukları hakları konusunda, bu hakları kullanma yani eyleme dönüştürme yeteneklerinin yeterli olmadığı,

- $\quad$ Bireysel farlılıklara genel anlamda saygılı bir yaklaşım benimsendiği,

- Hak arama özgürlüğü bağlamında vatandaşlar arasında eşitlik olmadığı yönünde bir kanaat taşındığı,

- Mezun olunan lisenin hak arama bilinci üzerinde etkili olduğu,

- Sorunlarının çözümünde adalet veya kolluk hizmetleri yerine farklı seçeneklerden yararlanma güdülerinin bulunduğu,

- $\quad$ Siyasal hak ve ödevleri konusunda bilinç düzeylerinin yüksek olduğu, hatta siyasal hayata katılımda bu farkındalıklarını uygulamaya geçirmekten çekinmeyecekleri,

- Eşitliğin özellikle cinsiyet boyutuyla ilgili olumlu yaklaşımlara sahip olunduğu,

- Hak arama bilincinin yerleştirilmesi ve bu konuda özgüven oluşmasında ailenin yadsınamaz bir etkisi bulunduğu,

- Hakların ve sorumlulukların öğrenilmesi açısından eğitimin bir ihtiyaç hatta zorunluluk olduğuna inanıldığı saptanmıştır.

Belirlenen sorun ve yetersizliklerin çözümünde haklar, özgürlükler, birey olma, vatandaşlık, sorumluluklar vb. konularda çocukluk çağından başlayarak eğitim verilmesi atılacak en önemli adım olacaktır. Hak ve sorumluluk bilinci aşısının tutabilmesi için bu 
eğitim sürecinin aileyi de kapsayacak şekilde uygulanması gerekmektedir. Amaca ulaşılabilmesi için ulusal düzeyde ilgili bakanlık tarafindan atanacak birim ya da bölüm koordinatörünün tüm ulusal eğitim kurumları ve hane halkı ile yakın ilişki içerisinde çalışması tavsiye edilebilir. Ayrıca ulusal düzeydeki insan hakları eğitimi için özellikle uluslararası kuruluşlardan finansal destek sağlanarak, bu eğitimden beklenen çıktıların toplumsal etkisi artırılabilir.

Çalışmaya teorik bir çatı oluşturmak amacıyla gerçekleştirilen literatür taraması sırasında, çalışmanın analiz kısmında yapılan anket çalışması ile yakın özelliklere sahip çalışmalara rastlanmamıştır. Bundan sonra hak arama bilinci üzerine gerçekleştirilecek olan çalışmaların eğitimin tüm kademelerini kapsayacak şekilde geliştirilmesi sayesinde, bu alandaki boşluğun doldurulacağı kanaatindeyiz.

\section{KAYNAKLAR}

Akdemir, Müslim (2005) “Temel Hak ve Özgürlükler Açısından İnsanın Doğası”, Kayg1/Uludağ Üniversitesi Felsefe Dergisi, (4), ss. 74-79.

Altunya, Niyazi (2003) Vatandaşlık Bilgisi, Nobel Yayın Dağıtım, Ankara.

Bajaj, Monisha (2011) "Human Rights Education Ideology, Locational and Approachs" Human Rigts Quarterly, Johns Hopkins University Pres, C.33, pp.481-508.

Bajaj, Monisha (2012) “From 'Time Pass' to Transformative Force: School-based Human Rights Education in Tamil Nadu, İndia" International Journal of Educational Development, 32, pp.72-80.

Bowring, Bill (2012) “Human Rights and Public Education” Cambridge Journal of Education, C.42, pp.53-65.

Caymaz, Birol (2007) Türkiye'de Vatandaşlık: Resmi İdeoloji ve Yansımaları, İstanbul Bilgi Üniversitesi Yayınları, İstanbul.

Clapham, Andrew (2010) İnsan Hakları, Dost Kitabevi Yayınları, Ankara.

Coşkun, Vahap (2006) İnsan Hakları: Liberal Açıdan Bir Tahlil, Liberte Yayınları, Ankara.

Çeçen, Anıl (1995) İnsan Hakları, Gündoğan Yayınları, Ankara.

Çotuksöken, Betül (2010) İnsan Hakları Ve Felsefe, Papatya Yayıncılık Eğitim, İstanbul.

Çüçen, A. Kadir (2011). İnsan Hakları, Mkm Yayıncılık, Bursa.

Dağı, İhsan D. Ve Polat, Necati (1999) Demokrasi Ve İnsan Hakları El Kitabı (Demokrasi Ve İnsan Hakları Eğitimi Projesi), Türk Demokrasi Vakfı, Ankara.

Doğan, İsmail (2007) Modern Toplumda Vatandaşlık, Demokrasi Ve İnsan Hakları: İnsan Haklarının Kültürel Temelleri, Pegem A Yayıncılık, Ankara. 
Duman, Tayip; Karakaya, Necmettin Ve Yavuz, Nuri; (2003) Vatandaşlık Bilgisi, Gündüz Eğitim Ve Yayınc1lık, Ankara.

Ekşi, Aysel (2009) Günümüzde Dünyada Yurttaşlık Bilinci, Çağdaşlık Ve Yurttaşlık Bilinci, Cumhuriyet Kitapları/Siyasi Yazılar, 2. Bask1, İstanbul.

Emini, M. Emin (2004) “Hak Kavramı” Selçuk Üniversitesi Sosyal Bilimler Enstitüsü Dergisi Sayı 12, Ss. 203- 216.

Flowers, Nancy; Bernbaum, Marcia; Rudelius-Palmer, Kristi And Tolman, Joel (2000) The Human Rights Education Handbook: Effective Practices For Learning, Action And Change, The Human Rights Resource Center And The Stanley Foundation, Minneapolis, Mn.

Freeman, Michael (2008) İnsan Hakları: Disiplinlerarası Yaklaşım, Birleşik Yayınları, Ankara.

Gören, Zafer (2000) Temel Hak Genel Teorisi, Dokuz Eylül Üniversitesi Yayını, 4. Bası, İzmir.

Gülmez, Mesut (1996) İnsan Hakları Eğitimi Hakkı, Türkiye Ve Ortadoğu Amme İdaresi Enstitüsü, İnsan Hakları Araştırma Ve Derleme Merkezi Yayın No: 10, Ankara.

Gülmez, Mesut (1998) Belgelerle İnsan Hakları Eğitimi: Birleşmiş Milletler Onaylı, Türkiye Ve Ortadoğu Amme İdaresi Enstitüsü, İnsan Hakları Araştırma Ve Derleme Merkezi Yayın No: 15, Ankara.

Gündoğan, Gülsün Ve Günay, Mustafa (2004) İnsan Hakları Eğitimi, İlya Yayınevi, İzmir.

Gündoğdu, Kerim (2011) “Candidate Teacher's Attitudes Concerning Human Rights Education İn Turkey” Turkish Education Assoc, C.36, Pp.182-195.

Gündüz, Mustafa Ve Gündüz, Ferhan (2007) Yurttaşlık Bilinci, Anı Yayıncılık, Ankara.

Hotaman, Davut (2010) "Demokratik Eğitim: Demokratik Bir Eğitim Programı", Kuramsal Eğitimbilim, 3(1), Ss.29-42.

Kan, Çiğdem (2009) “Sosyal Bilgiler Eğitiminde Küresel Vatandaşl1k”, Pamukkale

Üniversitesi Eğitim Fakültesi Dergisi, Sayı: 26, Ss. 25-30.

Kıncal, Remzi Y. Ve Uygun, Selçuk (2006) "Demokrasi Eğitimi Ve Okul Meclisleri Projesi” Uygulamalarının Değerlendirilmesi”, Milli Eğitim, (Yaz), Sayı: 171, Ss. 31-42.

Kymlıccka, Will Ve Norman, Wayne (2008) Vatandaşın Dönüşü: Vatandaşlık Kuramındaki Yeni Çalışmalar Üzerine Bir Değerlendirme (Vatandaşlığın Dönüşümü, Üyelikten Haklara), Metis Yayınları, İstanbul.

Milli Eğitim Bakanlığı Tebliğler Dergisi (2004) Demokrasi Eğitimi Ve Okul Meclisleri Projesi Yönergesi 2004/2564, Http://Mevzuat.Meb.Gov.Tr/Html/2564_0.Html (Erişim Tarihi: 27.11.2012). 
Osler, Audrey And Starkey, Hugh (2010) “Teachers And Human Rights Education” Trentham Boks Ltd., June Isbn-10:1858563844.

Özpolat, Vahap (2010) "Bir Toplumsal Değişme Paradigması Olarak Demokrasinin Eğitime Yansımaları: Demokratik Eğitim”, Milli Eğitim Dergisi, (Kış), Sayı: 135, Ss. 365-381.

Soysal, Yasemin (1994) Limits Of Citizenship, University Of Chicago, Chicago And London.

Suarez, David F. Ve Ramirez, Francisco O. (2004) Human Rights And Citizenship: The Emergence Of Human Rights Education, Center On Democracy, Development And The Rule Of Law, Stanford, Ca.

Tezcan, Durmuş; Erdem, Mustafa Ruhan; Sancaktar, Oğuz Ve Önok, Rıfat Murat (2009) İnsan Hakları El Kitabı, Seçkin Yayıncılık, Ankara.

Tibbits, Felisa (2008) Human Rights Education, İn: Bajaj,M. (Ed.) Encyclopaedia Of Peace Education, Information Age Publishing, Charlotte, Nc.

United Nations (2006) Plan Of Action: World Programme For Human Rights Education, United Nations, Ny And Geneva.

Uslu, Cennet (2009) Doğal Hukuk Ve Doğal Haklar, Liberte Yayınları, Ankara. 
